\title{
The oral tradition of sansana bandar of Dayak Ngaju, Central Kalimantan: religious function and inheritance challenge in global era
}

\author{
Titik Wijanarti ${ }^{1}$, Bani Sudardi ${ }^{2}$, Mahendra Wijaya $^{3}$, Sri Kusumo Habsari ${ }^{4}$ \\ $\left\{\right.$ thitikwijanartibjbr@gmail.com, ${ }^{2}$ banisudardi fssr@, staff.uns.ac.id, \\ ${ }^{3}$ mahendrawijaya@staff.uns.ac.id, ${ }^{4}$ skhabsari@staff.uns.ac.id\} \\ ${ }^{1,2,3,4}$ Postgraduate Program in Cultural Studies, Sebelas Maret University, J1. Ir. Sutami 36A, Surakarta \\ 57126, Indonesia
}

\begin{abstract}
The purpose of this research is to study the challenge of the preservation of Sansana Bandar in the face of the complexities of modern era. Sansana Bandar is an oral tradition of Dayak Ngaju, Central Kalimantan, Indonesia presented orally without any musical instrument accompanying the performance. Sansana Bandar has a lot of stories, however, mostly narrate the life stories of Bandar figure from his birth to his maturity and getting married. The existence of Sansana Bandar is almost extinct despite its stories which provides various life values. Traditionally, Sansana Bandar has religious function which is in the past it was held as a pray to achieve the future goals. Thus, through ethnographic method, this study observes and interviews the actors of the tradition to understand the problems and challenges to preserve the tradition. Finding of the study, just like any finding of ethnographic method, is the life stories of the actors who attempt to preserve the tradition, to find out their reasons why Sansana Bandar needs to be preserved, and their challenge and effort to preserve it.
\end{abstract}

Keywords : sansana Bandar-oral tradition-dayak-Central Kalimantanglobalization.

\section{Introduction}

The socio-cultural life of the etnic community in Indonesia has entered a new chapter that is the current era of globalization which has brought about great change impacts. Ritzer[1] defines globalization as the dissemination of practices, relationships, awareness, and organizations throughout the world. Meanwhile, Barker[2] looked at globalization not only with regard to the question of the economy but also with regard to cultural issues. Abdullah[3] suggests that the process of globalization has given rise to widespread differentiation, which can be seen from the process of the formation of the lifestyle and identity. A lifestyle formed in line with the emergence of the culture of the city, has changed the orientation of the society from a group oriented into more individual and material values with new symbolic boundaries. 
Indonesian community now faces two cultural phenomena that intersect each other, namely oral traditional-ethnic culture and modern-national-writing culture. A wide range of traditional oral products now face a challenge to keep it survive in the midst of the community. Barker[2] has stated that the oral tradition must "adapt" to be able to survive in modern societies today. One of the challenges faced by the oral traditions in Indonesia is the challenge of succession. Inheritance is one of the factors determining whether an oral tradition would be able to survive in the midst of changing times or it will experience extinction because of being eroded by the modern socio-cultural change

Sansana Bandar is an oral tradition of Central Kalimantan Dayak which is facing inheritance challenge in this era. Generally, sansana is an ethnic tale, saga, epic, epoch chanted like karungut. It is legendary[4]. There are different kinds of Sansana in Dayak, based on the content of the story and the performance. From the name, sansana Bandar is sansana about Bandar: a story about a figure named Bandar. It is narrated that Bandar has the quality of handsomeness, greatness and smartness, more than ordinary people. In Dayak Ngaju community's life, Sansana Bandar does not only have entertainment function but also religious function. This tradition has been used as medium to utter their pray to reach their goals. Central Kalimantan Dayak community believes that by performing oral tradition of sansana Bandar, their goals can be achieved. At the moment, the religious function of sansana Bandar in Dayak community's life still exists. However,over the time following the changing of the society with the coming of the new values which intersect with the local values, the religious function has been adjusted to meet the community's shift in perspective toward the tradition. Therefore, the religious function of sansana Bandar and the challenges of inheritance attract to study to understand the perspective of the actors in their attempt to preserve the tradition.

The study of sansana Bandar is still rarely conducted. One of the studies pertaining to sansana has been conducted by Asi[5]. Asi conducted a study of sansana in Mantangai Subdistrict, Kapuas District. Asi's study shows that sansana is still being carried out in Pulau Kaladan Village, Mantangai Subdistrict to date. The community carries out sansana as an effort to perform ancestral tradition. Asi's study describes the process of carrying out sansana and does not focus on sansana Bandar in relation to religious and inheritance functions in the global era. Other studies that have been carried out previously and raised the focus of the study of oral traditions in Central Kalimantan include conducted by Effendi[6], [7], [8], and [9]. While, the other studies observing oral traditions related to religious function in community have been conducted by Kamaluddin [10],[11], and [12]. Nevertheless, those studies do not observe the inheritance process but focus more on the relation between community and the values of religiosity in oral tradition.

\section{Research Methods}

In general, this research belongs to ethnographic studies. Ethnography is an attempt to understand the life of a community group based on their perspective. As Malinowsky argues, the ethnographic goal is to understand the point of view of indigenous peoples, their relation to life, to get their views on their world[13]. In accordance with the principles in ethnography, this study utilizes field observation techniques and interviews with informants to obtain research data accurately. The data collection area of this study is Kapuas District, Central of Kalimantan. 


\section{Results And Discussion}

\subsection{Sansana Bandar Concept}

Sansana Bandar was born and developed in Dayak Ngaju community of Central Kalimantan, especially in communities living in the Kapuas watershed, part of the Kahayan watershed, and the Katingan watershed. In recent times, sansana Bandar can still be found in the Kapuas watershed and part of the Kahayan watershed. There are many titles of sansana Bandar, but all of them have an equation pattern, that is, a long story that describes the life of Bandar figure from birth to adulthood. Sansana Bandar is oral-spontanous so that it really depends on the capability of the speaker (pangasana). Nevertheless, sansana Bandar performance always needs a long time because it tells the life journey of Bandar figure. The language used in sansana Bandar is Dayak Ngaju Language accompanied by some vocabularies of the Sangiang Language (Sangiang Language is a language used in the holy book of Kaharingan people, namely, the Book of Panaturan). The entry of the Sangiang Language vocabularies in sansana Bandar is closely related to the background of the community that gave birth to sansana Bandar, namely, the Kaharingan community. However the entry of Banjar and Malay vocabularies is caused by the movement of events in the stories with Banjar and Betawi backgrounds.

Sansana Bandar is delivered by pangasana without any accompaniment. He will tell the story with special tones like someone who is singing. The audience can watch the Sansana Bandar casually by sitting around the pangasana. During the performance, the pangasana will pause the story if he needs to drink or eat as little as possible. In the process of delivering stories, the pangasana can slip humor so that the audience will laugh. The purpose of the humor in the performance is to make the show not boring so the audience will not be sleepy until morning. The audience is also allowed to comment directly on the stories delivered by pangasana. The comments given by the audience are usually responses to the humor that is spoken by pangasana. It makes the atmosphere feel alive and fresh. During the performance the audience is also allowed to eat, drink, or smoke casually.

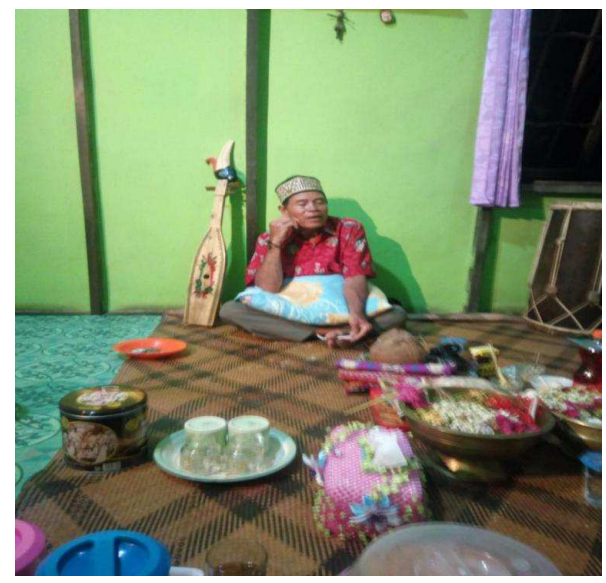

Figure 1. A pangasana is delivering sansana Bandar in the region of Kapuas, Central Kalimantan.

The performance of sansana Bandar has some rules that must be obeyed by everyone who will perform it. Before the show begins, the host must prepare some items as offerings that 
must be provided during the performance. In this case, the pangansana will tell the host as a person who has certain expectation the items he should prepare for the offerings. Each item that is included in the offerings in sansana Bandar has certain symbol and meaning.

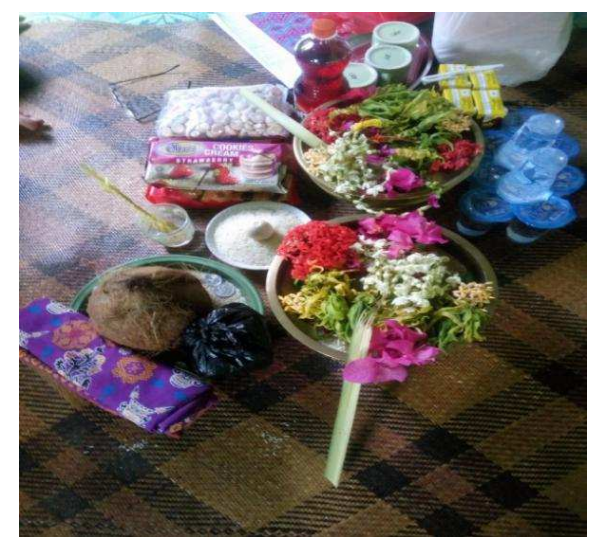

Figure 2. Various items for offering that must be provided before the performance.

\subsection{The Religious Function of Sansana Bandar as An Oral Tradition}

Sansana Bandar has religious function as a medium or a means of connecting to God to express hopes, prayers, goals, and gratitude. All hopes, pray, and good purposes can be conveyed through Sansana Bandar. Nowadays, this function can still be found in the life of Dayak community although it has a different context compared to the past. In principle, these functions have similarities. Sansana Bandar in the life of community in the past was often used as a medium to pray and express their goals in life, for instance, when Dayak people would build a house pole, open a new agricultural field, carry out a wedding ceremony, and greet the birth of children in the family. When these ideals were achieved, the community would again hold sansana Bandar as an expression of gratitude for the achievement

Sansana Bandar in today's life is still often carried out as a medium to convey various kinds of ideals that are substantially same as those of the past. These ideals include certain purposes like when a child is going to move away and make a living in another place, the parents will hold sansana Bandar so that the child is safe during the trip and successful in the new place. In addition, sansana Bandar is also carried out by the community when they will face a school exam, when they will take a skill assessment test for certain jobs, when they will propose themselves a head of the certain region, etc.

Recently there are interesting facts that sansana Bandar is often carried out by the community to treat longing for their tradition and culture of the past. Longing for the past and also the hometown is often used as an excuse for the community to hold sansana Bandar. The purposes conveyed in the context of the performance are generally in the form of prayers so that the whole family is given happiness and prosperity. This description represents a new meaning for sansana Bandar. It is not only seen by community as an oral tradition that has a ritual function but also as a symbol of the traditionality they long for. In the life that is full of the bustle of modernity, people long for something traditional and sansana Bandar is considered adequate for representing it.

Textually, the ideals or intentions conveyed in the performance of sansana Bandar will usually be conveyed in the middle of the story by the pangasana. The following is an example 
of the intentions conveyed in the midst of sansana Bandar Busu Hanyut Sansana performance. The sansana is carried out with the certain purpose, that is, someone who holds the performance can study well without any problem.

\begin{tabular}{|l|l|}
\hline $\begin{array}{l}\text { Kalute kea Bandar anak Tamanggung } \\
\text { manenga akan ewen Pantai Danum } \\
\text { Kalunen awing bahjat baniat manduan } \\
\text { sekoalah balaku ikau mandampingi iye } \\
\text { melai likut saritae, amun iye juru bahasa } \\
\text { pamarentah balaku oloh tunduk dengae. }\end{array}$ & $\begin{array}{l}\text { Likewise Bandar the son of Tamanggung } \\
\text { gives them who vow to study, I beg you to } \\
\text { accompany him, if he has to answer the } \\
\text { questions asked by the lecturers, hopefully, } \\
\text { they will help him. }\end{array}$ \\
$\begin{array}{l}\text { Iyoh ewen Batang danum balaku ikau } \\
\text { mandampingi huang kantor kilau ikau } \\
\text { anak tamanggung Kapala hapan mamutus } \\
\text { perkara halus. }\end{array}$ & $\begin{array}{l}\text { Yes, for those who have requests I beg you } \\
\text { to accompany them in the class, like you as } \\
\text { the of Tamanggung Kapala when you } \\
\text { solved various kinds of problems. }\end{array}$ \\
$\begin{array}{l}\text { Kalute ke pagantung titel, balaku oloh } \\
\text { tunduk manun auh kahandak huang, } \\
\text { balaku nenga kea pangirik lingu ewen } \\
\text { pantai Danum Kalunen balaku kahandak } \\
\text { tapacapai akan ikei oloh Pantai Danum } \\
\text { Kalunen }\end{array}$ & $\begin{array}{l}\text { Likewise make them gain high academic } \\
\text { degrees, I beg people to give love for them } \\
\text { according to their wishes. Please also give } \\
\text { them intelligence, they also hope their will } \\
\text { can be granted. }\end{array}$ \\
$\begin{array}{l}\text { Ji nenga kea parentai rawei ikei pantai } \\
\text { Danum Kalunen Balaku behas hambaruan } \\
\text { barintik halawu upun tundue,hariten } \\
\text { halawu benteng, jiakan ewen pantai } \\
\text { danum Klaunen barigas mangat }\end{array}$ & $\begin{array}{l}\text { Also please give them who make vows the } \\
\text { ability to speak well. Please that the rice } \\
\text { wrapped in small white cloth can restore the } \\
\text { soul and the spirit. For those who vow this, } \\
\text { hopefully they can be healthy and spirited. }\end{array}$ \\
\hline
\end{tabular}

Utterances of expectation to Bandar that resemble a pray are repeated by pangasana for several times, in the middle of the story and in the end of the story. In accordance with the movement of the events in the story, usually in the middle and in the end of the story, it will be found that Bandar figure carries out a ritual to utter the pray and expectations, as request of those who holds Sansana Bandar.

\subsection{Preservation Challenge of Sansana Bandar in the Global Era}

Sansana Bandar experiences preservation challenges. First, the preservation of Sansana Bandar from one speaker to the next generation of speakers. So far, the ability to become a Sansana speaker (pangasana) can only be obtained naturally. This has become an obstacle in terms of the regeneration process of pangasana. Based on the observations made in the region of Kapuas watershed, nowadays, there are only few pangasana. In principles, there are actually no special requirement for someone to become pangasana. The prospective pangasana could be any sex, a man or a woman. The specific requirement to be a pangasana is the ability to master the story of sansana Bandar and the ability to retell it well. The main difficulty in this preservation is that sansana Bandar cannot be transmited through special training. While, it is not easy to find somebody who is interested in learning the story of Sansana Bandar, memorizing it and retelling it. In accordance, the audience of Sansana 
Bandar is also few in number. As a result, people who master the story of Sansana Bandar who are expected to become the next generation of the speakers are also fewer. Such situation makes sansana Bandar now begins to scarce.

Second, Sansana Bandar should be preserved and transmitted from one generation of the community to the next community. Various global culture that massively enters the social spaces of the community causes lack of interest of the Dayak comunity towards oral traditions, including sansana Bandar. The advance information technology system which could enter the private space of individuals of community, even the rural or isolated area, such as on the banks of the river of Kapuas diverts people's lifestyle from traditional to modern. They then switch from oral culture to cyber culture. In this condition, sansana Bandar as an oral tradition is marginalized. Nevertheless, in the point of view of the orality concept, the community still does not abandon oral culture. Cyber technology engineering such as video call or teleconference is possible to foster the culture of orality itself. The preversation of sansana Bandar in its context as an ancient tradition of orality today only relies on the trust of the part of the community who still believe that sansana Bandar has religious function besides entertainment function. The third challenge is the preservation of locality values contained in sansana Bandar. An oral tradition certainly always contains wisdom values that serve as a life guide as well as the cultural identity of a community group. The cultural identity is formed through distinctive values that are built into the text so that they can be distinguished from other community groups. Djuweng [14] states that in oral tradition it will be found philosophy, history, moral values, ethics, religiosity, customary law, structure and social organization. Oral tradition also contains knowledge and methods in it.

Sansana Bandar is one of Dayak oral traditions that is still very less exploited in terms of locality values contained in it. This is caused by two factors. First, the lack of socialization of sansana Bandar in the community. The fewer people who carry out sansana Bandar, the fewer people who possibly know and understand the values contained in sansana Bandar. Second, the lack of interest of researchers to study sansana Bandar also causes the local wisdom contained is not well documented and socialized to the community.

Based on discussion above, it can be found that there is a relation between the three variables of preservation challenges that should be faced by sansana Bandar. The basic problem of the three variables is the lack of interest to hold sansana Bandar. The changing times can be referred as the main factor that shifts the community so that it results in the lack of enthusiasm to hold sansana Bandar. While on the other hand, change is something that cannot be avoided. Every community will experience the changing times and this affects the orders as well as the different cultural tastes. The shared awareness that needs to be increased to preserve sansana Bandar includes the same understanding of the preservation concept. Manuaba [15] borrows Singleton's concept of preservation. The concept of "preservation" should no longer be given the meaning "remain as the original state, unchanging, and eternal". It should be realized that the concept of "preservation" actually contains the notion of continuity and change. Preservation of Sansana Bandar should be carried out in accordance with the concept that Sansana Bandar must be preserved by new modification and creativity in order to survive in the community through various kinds of changing times. A more creative breakthrough of the preservation system needs to be considered so that it can compromise with the modern values accompanying the changing time. Banda agrees with Pudentia's statement who states that an oral tradition cannot stand alone as an influence-free tradition. Cultural development shows that saving a tradition in the package of past traditions will weaken the tradition. The cause of the distinction of a tradition is triggered by the assumption that tradition is something ancient or part of the past [16]. 


\section{Conclusion}

It can be assured that all of oral traditions are facing challenges in preservation in this global era. Sansana Bandar as one of oral traditions of Central Kalimantan Dayak is also facing that challenges. Inheritance is a challenge that has to be answered immediately in order to preserve sansana Bandar. However, a good collaboration between all parties that are involved is needed to find the way to preserve the tradition in accordance with the changing times without ruining the great values contained in sansana Bandar. In accordance with the principles, all of oral traditions are flexible based on the agreement between the speakers and the audiences.

\section{References}

[1] Ritzer George, Teori Sosiologi Klasik sampai Perkembangan Terakhir Postmodernisme. Yogyakarta: Pustaka Pelajar, 2012.

[2] C. Barker, Cultural Studies Teori dan Praktik. Bantul: Kreasi Wacana, 2018.

[3] I. Abdullah, Konstruksi dan Reproduksi Kebudayaan. Yogyakarta: Pustaka Pelajar, 2015.

[4] A. \& O. A. I. Bingan, Kamus Dwibahasa Dayak Ngaju Indonesia, 3rd ed. Palangka Raya: CV Primal Indah, 2005.

[5] Y. M. E. Asi, "Tradisi lisan sansana pada masyarakat Dayak Ngaju di Desa Pulau Keladan Kecamatan Mantangai Kabupaten Kapuas," Socius (Jurnal Pendidik. Pembelajaran Ilmu Pengetahuan. Sos., vol. 5, no. $2,2016$.

[6] C. Effendi, "Oral tradition and identity of West Kalimantan society," SARI J. Alam dan Tamadun Melayu, vol. 27, no. 1, pp. 3-12, 2009.

[7] H. Sion and M. Affandi, "Function of traditional art karungut in character building education of Dayak people in Central Kalimantan," vol. 262, no. Ictte, pp. 149-152, 2018.

[8] H. Porda Nugroho Putro, "The values in Nyai Undang legend for learning social sciences in Central Kalimantan," Procceding 3rd Int. Semin. Soc. Stud. Hist. Educ. 2018, vol. 10, no. 2, pp. 1-15, 2018.

[9] L. Schroeder, "An analysis of sama oral traditions about monkeys," Borneo Res. J., pp. 79-94, 2019.

[10] M. Kamaluddin, "Religiosity of Cirebonese society of culture in the oral tradition pepujian," Adv. Soc. Sci. Humanities Res., vol. 82, pp. 289--292, 2017.

[11] Okediji and Hannah Adebola Aderonke, "Effect of oral traditions, folklores and history on the development of education in Nigeria, 1977 till date," J. Hist. Res., vol. 7, no. 2, pp. 59-72, 2017.

[12] C. Chia, "Negotiation between a religious art form and the secular state," Asian Ethnol., vol. 76, no. 1, pp. 117--144, 2017.

[13] J. P. Spradley, Metode Etnografi. Yogyakarta: Pustaka Pelajar, 2007.

[14] S. Djuweng, "Tradisi lisan Dayak dan modernisasi : Refleksi metodologis penelitian sosial positif dan penelitian parsipatoris," in Metodologi Kajian TradisiLlisan, Pudentia, Ed. Jakarta: Yayasan Obor Indonesia, 2015.

[15] P. Manuaba, "Budaya daerah dan jati diri bangsa: Pemberdayaan cerita rakyat dalam memasuki otonomi daerah dan globalisasi," Masyarakat, Kebudayaan, dan Politik., vol. XIV, no. 4, pp. 57--66, 1999.

[16] B. W. Setyawan and K. Saddhono, "Eret traditional ceremony as representation of spirit of mutual cooperation among coastal communities," Adv. Sci. Lett., vol. 23, no. 10, 2017. 